\title{
STUDY OF THE TECHNICAL TRAINING SYSTEM OF YOUNG ATHLETES
}

\author{
Koryahin V., Blavt O. \\ National University "Lviv Polytechnic"
}

Corresponding Author: Blavt O., e-mail: oksanablavt@ukr.net

Accepted for Publication: June 20, 2019

Published: June 25, 2019

DOI:10.17309/tmfv.2019.2.02

\begin{abstract}
The purpose of the research is to investigate the dynamics of technical preparedness of basketball players at different stages of their training and the systems of time distribution for its development in young basketball players in the process of a long-term training.

Materials and methods. The analysis of literature and the summary of practical experience of basketball coaches, and skills generalization. The existing programs and the system of training basketball players of all ages have been analyzed. Young basketball players aged 11-17 years have been tested.

Results. The study results have revealed that the effectiveness of the system of long-term training of basketball players will improve significantly if at all stages of sports improvement, the training is conducted taking into account a science-based strategy dealing with age-related peculiarities of sportsmen and model characteristics.

Conclusions. The existing programs and training systems do not sufficiently take into account the importance of technical skills in basketball. The age peculiarities of the development of young basketball players are not taken into account. The identified level of technical preparedness of basketball players of all ages confirms the need to revise the training system in terms of increasing the role of mastering the skills of the game technique at stages from 11 to 17 years old.

Keywords: basketball, player, technical preparedness, training, skills.
\end{abstract}

\section{Introduction}

Problem statement. Of particular importance for improving sport skills of basketball players is their technical preparedness, the groundwork, which is laid at an early age (Koryahin, Dutchak, Iedynak, Blavt, Galamandjuk \& Cherepovska, 2018). It has been proved that the disadvantages of technical skills during the transition to adult teams cannot be fully compensated by a sufficiently high level of physical training. In connection with this, the optimal distribution of technical training amounts at different stages of sport improvement and increasing the role of individual training is an important condition for the further process of training basketball players (Altberg, 1971; Koryahin, 1998; Poplavsky, 2004).

The achievement of the ultimate goals - the training of the highly qualified reserve depends on the programregulatory framework, the organization of the training process, the competition system and the creative approach to these issues of the coaching corps (Simion, Mihaila \& Stanculescu, 2011).

(c) Koryahin V., Blavt O., 2019.
Analysis of recent research and publications. The optimization of basketball training system is a complex problem that requires further research (Koryahin, Blavt \& Grebinca, 2016; Villa \& Lozano, 2018). The research analysis of this problem shows that it constantly attracts the attention of sports professionals (Afonshin \& Rozhentsov, 2016; Buceta, Mondoni, Avakumovic \& Killik, 2000; Ferreira, Volossovitch \& Sampaio, 2014; Simion et al., 2011). At the same time, it is being solved very slowly. The coaches of children and youth sports schools do not pay enough attention to the importance of technical training in their practice. Practically, the age characteristics of athletes as well as the development of their physical qualities are not sufficiently considered (Colibaba \& Bota, 1998; Karpowicz, K. \& Karpowicz, M. 2013; Semashko, 1976).

There are thoughts that (Allawi, 1992; Makarov, 2013; Okazaki \& Rodack, 2018) the problem of basketball players technical training can be solved by finding the optimal way of distribution of technical training at different stages of sports improvement, by increasing the role of individual training. The attention of basketball experts is drawn to the fact that the hitherto known basketball programs do not take into account 
that the mastering of playing techniques depends on mobility opportunities in accordance with the age of sportsmen (Altberg, 1971; Semashko, 1976). There is evidence (Ben Abdelkrim, Castagna, El Fazaa \& El Ati, 2010; Gryko, Mikołajec, Maszczyk, Cao \& Adamczyk, 2017; Ferreira, Volossovitch \& Sampaio, 2014) that we need to pay considerable attention to basketball players technical training taking into account a science-based strategy for age-related characteristics.

The purpose of the research is to investigate the dynamics of technical preparedness of basketball players at different stages of their training and the systems of time distribution for its development in young basketball players in the process of a long-term training.

\section{Materials and methods}

\section{Study participants}

The study participants were boys aged 11 years $(\mathrm{n}=105), 12$ years $(\mathrm{n}=101), 13$ years $(\mathrm{n}=115), 14$ years $(n=101), 15$ years $(n=102), 16$ years $(n=101)$, 17 years $(n=109)$. The children and their parents were fully informed about all the features of the study and gave their consent to participate in the experiment.

\section{Study organization}

The analysis of literature and the summary of practical experience of basketball coaches, and skills generalization. The existing programs and the system of training basketball players of all ages have been analyzed. Young basketball players aged 11-17 years have been tested.

\section{Testing procedure}

The assessment of technical preparedness has been carried out in the following tests:

1. Pressing in the protective stance, $100 \mathrm{~m}$.

2. Complex exercise in passing, handling and throwing the ball into the basket.

3. Penalty throws, out of 30 throws.

4. Throws from certain points, out of 40 throws.
5. Playing a give-and-go (Buceta et al., 2000; Koryahin, 1998; Matiegka, 1991; Semashko, 1976).

\section{Statistical analysis}

For every variable, the study calculated the following: mean values, standard deviations.

\section{Results of the research}

The research has shown that at all stages of training - from initial groups to groups of sports improvement - quite a stable considerable amount of physical activity focuses on playing techniques. As for the comments on general and special physical training, their relative amount has gradually shifted to finishing basketball sports school, regardless of the physical characteristics of the body and the mechanism of age development of physical qualities: agility, speed, strength, endurance. The results of time distribution in existing programs for all types of training for young basketball players are given in Table 1.

As one can see in Table 1, the programs do not sufficiently take into account the importance of technical skills of basketball players. The age-specific features of the development of sportsmen and the formation of their qualities are almost ignored. It is clearly seen in Table 1 that at all stages of training, from the basic groups to the sports improvement groups, the amount of technical training is almost the same. Regarding the amounts of general and special physical training, their relative amount systematically reduces up to the age of 17 years, regardless of the physical characteristics of the sportsman and of the patterns of age development of such qualities as agility, speed, strength and endurance.

The planning and performance of physical activity must consider both relatively restricted age zones and the most suitable ones for the development of certain physical qualities and playing techniques. It is recommended to shift the pedagogical influence especially for athletes of 10-13 and 16 years old, when all systems of the body are intensively developing. The hitherto known basketball programs do not take it into account. General and special physical training of 10-12-year-

Table 1. Time distribution in the program for all types of training for young basketball players, $\%$

\begin{tabular}{|c|c|c|c|c|c|c|c|c|c|}
\hline \multirow{3}{*}{ Types of training } & \multicolumn{9}{|c|}{ Groups of } \\
\hline & \multicolumn{2}{|c|}{ Basic Training } & \multicolumn{4}{|c|}{ Teaching-and-Training } & \multicolumn{3}{|c|}{ Sports Improvement } \\
\hline & $\begin{array}{l}10-12 \\
\text { years }\end{array}$ & $\begin{array}{c}11-13 \\
\text { Years }\end{array}$ & $\begin{array}{c}13-14 \\
\text { years }\end{array}$ & $\begin{array}{c}13-15 \\
\text { years }\end{array}$ & $\begin{array}{c}14-16 \\
\text { years }\end{array}$ & $\begin{array}{l}15-16 \\
\text { years }\end{array}$ & $\begin{array}{c}16-18 \\
\text { years }\end{array}$ & $\begin{array}{c}17-19 \\
\text { years }\end{array}$ & $\begin{array}{l}18-20 \\
\text { years }\end{array}$ \\
\hline General Physical Training & 31.5 & 33 & 23 & 23 & 18 & 11 & 10 & 10 & 9.5 \\
\hline Special Physical Training & 18.5 & 16 & 17 & 16 & 16 & 15 & 13 & 13 & 12.5 \\
\hline $\begin{array}{l}\text { Technical } \\
\text { Training }\end{array}$ & 25 & 24 & 23 & 22 & 22 & 25 & 22 & 21 & 22 \\
\hline
\end{tabular}


Table 2. Results of studies of technical preparedness of basketball players of all ages

\begin{tabular}{|c|c|c|c|c|c|c|c|c|c|c|c|c|c|c|c|}
\hline \multirow[t]{2}{*}{ No } & \multirow[t]{2}{*}{ Indicators } & \multicolumn{2}{|c|}{$11(n=105)$} & \multicolumn{2}{|c|}{$12(n=101)$} & \multicolumn{2}{|c|}{$13(n=115)$} & \multicolumn{2}{|c|}{$14(n=101)$} & \multicolumn{2}{|c|}{$15(n=102)$} & \multicolumn{2}{|c|}{$16(n=101)$} & \multicolumn{2}{|c|}{$17(n=109)$} \\
\hline & & $\mathbf{X}$ & s & $\mathbf{X}$ & $\mathbf{s}$ & $\mathbf{X}$ & $\mathbf{s}$ & $\mathbf{X}$ & s & $\mathbf{X}$ & $\mathbf{s}$ & $\mathbf{X}$ & s & $\mathbf{X}$ & $\mathbf{s}$ \\
\hline 1. & $\begin{array}{l}\text { Moving in a defensive stance, } \\
100 \mathrm{~m}, \mathrm{sec}\end{array}$ & 41.9 & 1.97 & 38.1 & 1.95 & 36.6 & 2.85 & 34.24 & 1.97 & 35.93 & 2.01 & 33.1 & 1.95 & 32.9 & 1.91 \\
\hline 2. & Complex exercise $2 \times 26$ m,sec & 26.02 & 0.731 & 22.03 & 0.820 & 19.82 & 0.791 & 18.01 & 0.831 & 17.2 & 0.822 & 16.1 & 0.801 & 15.14 & 0.812 \\
\hline 3. & $\begin{array}{l}\text { Penalty throws, out of } 30 \\
\text { (number of baskets scored) }\end{array}$ & 7.42 & 3.01 & 10.1 & 2.97 & 14.55 & 2.94 & 15.4 & 2.85 & 16.1 & 2.11 & 17.4 & 2.15 & 20.1 & 2.01 \\
\hline 4. & $\begin{array}{l}\text { Penalty throws, out of } 40 \\
\text { (number of baskets scored) }\end{array}$ & 5.5 & 3.82 & 8.6 & 3.51 & 14.0 & 3.45 & 15.1 & 3.52 & 16.2 & 3.51 & 17.2 & 3.37 & 18.1 & 3.35 \\
\hline 5. & Give-and-go passes, number: & & & & & & & & & & & & & & \\
\hline- & with a "strong" hand & 18.5 & 3.15 & 19.4 & 3.01 & 22.9 & 2.91 & 25.8 & 2.6 & 27.9 & 2.51 & 29.1 & 2.32 & 32.2 & 2.41 \\
\hline- & with a "weak" hand & 11.2 & 3.19 & 14.3 & 2.97 & 17.1 & 2.95 & 20.1 & 2.71 & 22.1 & 2.49 & 25.5 & 2.75 & 29.1 & 2.33 \\
\hline- & $\begin{array}{l}\text { with both hands from the } \\
\text { chest }\end{array}$ & 16.2 & 3.1 & 18.08 & 3.07 & 21.1 & 2.41 & 24.1 & 2.69 & 26.4 & 2.61 & 27.2 & 2.61 & 31.01 & 2.15 \\
\hline
\end{tabular}

old athletes is given up to $50 \%$ of the time, 13 -year-old ones - up to $40 \%$.

The level of dexterity, coordination of basketball players' movements and the ability to apply all of this in complex in ever-changing situations are very important for mastering basketball playing techniques. Boys of 12-13 years old have well-developed motor and vestibular analyzers and when they are 11-14 years old their flexibility increases by approximately $25 \%$. This suggests that this is the most appropriate age to master playing techniques.

The planning and realization of amounts of physical activity should take into account both the forbidden age zones and the most appropriate ones for the development of certain physical qualities. The results of studies of the level of technical preparedness of basketball players of all ages (11-17 years) are shown in Table 2.

The results of the studies showed that the level of technical preparedness in young basketball players is insufficient and mostly does not correspond to the model indicators. This is especially evident in such indicators, as penalty throws and throws from points. In case of persons aged 13 to 15 years, the difference in these rates is insignificant. And at the same time, basketball players should master the maximum number of skills of the game technique, and indicators that characterize the game technique should have a greater dynamics of their increase.

\section{Discussion of the research results}

It is recommended to reduce amounts of pedagogical intervention in sportsmen aged 10-13, 16 years, when all systems of the body are intensively forming. The basketball programs do not take this into consideration. When training 11-12-year-old sportsmen, 50\% of time is devoted to general and special training, and in case of 13 -year-old sportsmen - up to $40 \%$. That is according to the available data (Allawi, 1992; Koryahin et al., 2018; Sporiš, Šango, Vučetić \& Mašina, 2006).
When mastering basketball techniques, the level of development of agility (coordination of movements) and the ability to apply the techniques in situations that are constantly changing during the game are of great importance (Afonshin et al., 2016; Ferreira et al., 2014; Karpowicz et al., 2013; Cooper \& Sirvent, 2009; Sporiš et al., 2006).

In children aged under $12-13$ years, motor and vestibular analyzers are well-developed and in children aged 11-14 years, the flexibility gain is approximately $25 \%$. That is according to the given literature (Buceta et al., 2000; Colibaba et al., 1998; Okazaki et al., 2018; Calvo, García \& Navandar, 2017).

This suggests that this age is most optimal for mastering the maximum number of skills of basketball technique. By the age of 12 , a child has mastered up to $90 \%$ of all motor skills. Insufficient use of motor abilities of young children at the stages of basic training complicates further sport improvement and does not allow to use a large range of skills of the game technique (Koryahin, 1998; Raiola, Altavilla, Tafuri \& Lipoma, M. 2016; Sampaio, Janeira, Ibáñez \& Lorenzo, 2006). It is in these age groups when the large amount of physical activity inhibits the development of technical skills. At the stage of initial sports specialization and in-depth training, athletes must master kinematic and dynamic aspects of motor skills in the mode which is required for the future competitive activity. At the age of 12-15, every new basketball player must master the playing techniques as the first thing. Now when the speed of the play has increased significantly, the level of mastery of playing techniques should be high (Allawi, 1992; Bompa, 2002; Buceta et al., 2000; Semashko, 1976; Simion et al., 2011).

\section{Conclusions}

1. The existing programs and training systems do not sufficiently take into account the importance of technical skills in basketball. The age peculiarities of 
the development of young basketball players are not taken into account. The effectiveness of the system of long-term training of basketball players, in terms of not only physical, psychological, tactical, but technical aspects, will increase significantly if at all stages of sports improvement the training is carried out taking into account a science-based strategy dealing with age-related peculiaritites.

2. The studies have shown that at all stages of training, from basic groups to sports improvement groups, there is a stable amount of time devoted to technical training.

3. The identified level of technical preparedness of basketball players of all ages confirms the need to revise the training system in terms of increasing the role of mastering the skills of the game technique at stages from 11 to 17 years old.

\section{Conflict of interest}

The authors state no conflict of interest.

\section{References}

Afonshin, V.E., \& Rozhentsov, V.V. (2016). The Method of Team Sports Athletes' Motor Skills Development. European Journal of Physical Education and Sport, 12(2), 34-40. https://doi.org/10.13187/ejpe.2016.12.34

Altberg, O.Ya. (1971). Study of the process of training and competitive loads intensification for basketball players of the highest ranks. Author's abstract. [dissertation] Tartu. (in Russian).

Allawi, M.H. (1992). The science of sports training. Cairo: Knowledge house, 412.

Ben Abdelkrim, N., Castagna, C., El Fazaa, S., \& El Ati J. (2010). The effect of players' standard and tactical strategy on game demands in men's basketball. Journal Strength Cond Res, 24, 2652-2662

Bompa, T.O. (2002). Periodizacao teoria e metodologia do treinamento. San Paulo: Phorte Editora Ltd., 424.

Buceta, J.M., Mondoni, M., Avakumovic, A., \& Killik, L. (2000). Basketball for Young players. Guidelines for coaches. Madrid: FIBA, 358.

Calvo, J.L, García, A.M, \& Navandar A. (2017). Analysis of mismatch after ball screens in Spanish professional basketball. Intern. Jour. of Performance Analysis in Sport, 17(4), 555-562. https://doi.org/10.1080/24748668.2017 .1367999

Colibaba, E.D., \& Bota I. (1998). Sports Games, Theory and Methodology. Bucharest: Publishing House Aldin, 470.

Cooper, W.W., Ruiz, J.L., \& Sirvent, I. (2009). Selecting non-zero weights to evaluate effectiveness of basketball players with DEA. European Journal of Operational Research, 195(2), 563-574. https://doi.org/10.1016/j. ejor.2008.02.012

Ferreira, A.P, Volossovitch, A., \& Sampaio, J. (2014). Towards the game critical moments in basketball: a grounded theory approach. Intern. Jour. of Performance
Analysis in Sport, 14(2), 428-442. https://doi.org/10.108 0/24748668.2014.1186873

Gryko, K, Mikołajec, K, Maszczyk, A, Cao, R, \& Adamczyk, J. (2017). Structural analysis of shooting performance in elite basketball players during FIBA EuroBasket 2015. Intern. Jour. of Performance Analysis in Sport, 18(2), 380-392. https://doi.org/10.1080/24748668.2018 .1479923

Karpowicz, K., \& Karpowicz, M. (2013). Structure of motor skills in young athletes. Human movement, 14(3), 221228. https://doi.org/10.2478/humo-2013-0027.

Koryahin, V.M. (1998). Training of highly skilled basketball players. Lviv: "The Edge”, 191. [in Ukrainian].

Koryahin, V., Blavt, O., \& Grebinca, G. (2016). Optimization of the technical training system. Journal of Physical Education and Sport, 16(2), 1029-1030. https://doi. org/10.7752/jpes.2016.s2163.

Koryahin, V., Dutchak, M., Iedynak, G., Blavt, O., Galamandjuk, L., \& Cherepovska E. (2018). The technical and physical preparation of basketball players. $\mathrm{Hu}$ man movement, 19(4), 29-34. https://doi.org/10.5114/ hm.2018.77321

Makarov, Yu.M. (2013). The concept of formation of game activity in sports games. Uchenye zapiski universiteta im. P.F. Lesgaft, 7, 78-83. (in Russian).

Matiegka, J. (1991). The testing of physical efficiency. Amer. Journal of Physical Anthropology, 4(3), 125-134. https:// doi.org/10.1002/ajpa.1330040302

Okazaki, H.A., \& Rodack, A.L.F. (2018). Basketball jump shot performed by adults and children. Human movement, 19(1), 71-79. https://doi.org/10.5114/ hm.2018.73615

Poplavsky, L.Y. (2004). Basketball. Kiev, publishing house "Olympic Literature", 446. (in Russian).

Raiola, G., Altavilla, G., Tafuri, D., \& Lipoma, M. (2016). Analysis of learning a basketball shot. Journal of Physical Education and Sport, 16(1), 1, 3-7. https://doi. org/10.7752/jpes.2016.01001

Sampaio, J., Janeira, M., Ibáñez, S., \& Lorenzo, A. (2006). Discriminant analysis of game-related statistics between basketball guards, forwards and centres in three professional leagues. European Jour. of Sport Science, 6(3), 173-178. https://doi. org/10.1080/17461390600676200

Semashko, N.V. (1976). Basketball. Moscow: Physical Culture and Sport. 264. (in Russian).

Simion, Gh., Mihaila, I., \& Stanculescu, G. (2011). Sports training, systemic concept. Ed. University Press, Constanta, 290.

Sporiš, G., Šango, J., Vučetić, V., \& Mašina, T. (2006). The latent structure of standard game efficiency indicators in basketball. Intern. Jour. of Performance Analysis in Sport, 6(1), 120-129. https://doi.org/10.1080/24748668. 2006.11868360

Villa, G., \& Lozano, S. (2018). Dynamic Network DEA approach to basketball games efficiency. Jour. of the Operational Research Society, 2(18), 1738-1750. https://doi. org/10.1080/01605682.2017.1409158 


\title{
ДОСЛІДЖЕННЯ СИСТЕМИ ТЕХНІЧНОЇ ПІДГОТОВКИ ЮНИХ СПОРТСМЕНІВ
}

\author{
Корягін В., Блавт О. \\ Національний університет «Львівська політехніка» \\ Реферат. Стаття: 5 с., 2 табл., 25 джерел.
}

\begin{abstract}
Мета дослідження - дослідити динаміку технічної підготовленості баскетболістів на різних етапах спортивного удосконалення та системи розподілу часу на технічну підготовку у юних баскетболістів.

Матеріали та методи. Для вирішення завдань дослідження використані аналіз літератури та узагальнення практичного досвіду тренерів баскетбольних команд. Були проаналізовані існуючі програми i система підготовки баскетболістів різного віку. Проведено тестування баскетболістів віком 11-17 років.

Результати. За результатами досліджень виявілено, що ефективність системи багаторічної підготовки баскетболістів значно покращиться, якщо на

всіх етапах спортивного удосконалення вона буде проводитися з урахуванням науково обгрунтованої стратегії вікових особливостей спортсменів і модельних характеристик.

Висновки. Існуючі програми і системи навчання недостатньо враховують важливість технічних навичок в баскетболі. Вікові особливості розвитку юних баскетболістів не враховуються. Виявлений рівень технічної підготовленості баскетболістів різного віку підтверджує необхідність перегляду системи тренувань 3 точки зору підвищення ролі оволодіння навичками ігрової техніки на етапах 311 до 17 років.

Ключові слова: баскетбол, гравець, технічна підготовленість, тренування, навички.
\end{abstract}

\section{ИССЛЕДОВАНИЕ СИСТЕМЫ ТЕХНИЧЕСКОЙ ПОДГОТОВКИ ЮНЫХ СПОРТСМЕНОВ}

\author{
Корягин В., Блавт О. \\ Национальный университет «Львивска политэхника» \\ Реферат. Статья: 5 с., 2 табл., 25 источников.
}

\begin{abstract}
Цель исследования - исследовать динамику технической подготовленности баскетболистов на различных этапах спортивного совершенствования и системы распределения времени на техническую подготовку у юных баскетболистов.

Материалы и методы. Для решения задач исследования использованы анализ литературы и обобщение практического опыта тренеров баскетбольных команд. Были проанализированы существующие программы и система подготовки баскетболистов всех возрастов. Проведено тестирование баскетболистов в возрасте 11-17 лет.

Результаты. По результатам исследований выявилено, что эффективность системы многолетней подготовки баскетболистов значительно улучшит-
\end{abstract}

ся, если на всех этапах спортивного совершенствования она будет проводиться с учетом научно обоснованной стратегии возрастных особенностей спортсменов и модельных характеристик.

Выводы. Существующие программы и системы обучения недостаточно учитывают важность технических навыков в баскетболе. Возрастные особенности развития юных баскетболистов не учитываются. Выявленный уровень технической подготовленности баскетболистов всех возрастов подтверждает необходимость пересмотра системы тренировок с точки зрения повышения роли овладения навыками игровой техники на этапах с 11 до 17 лет.

Ключевые слова: баскетбол, игрок, техническая подготовленность, тренировка, навыки.

\section{Information about the authors:}

Koryahin V. M.: koryahinv@meta.ua; orcid.org/0000-0003-1472-4846; National University «Lviv Polytechnic»; Str. Bandera, 12, Lviv, 79013, Ukraine

Blavt O. Z.: oksanablavt@ukr.net; http://orcid.org/0000-0001-5526-9339; National University «Lviv Polytechnic»; Str. Bandera, 12, Lviv, 79013, Ukraine

Cite this article as: Koryahin, V., \& Blavt, O. (2019). Study of the Technical Training System of Young Athletes. Teoriâ ta Metodika Fizičnogo Vihovannâ, 19(2), 64-68. https://doi.org/10.17309/tmfv.2019.2.02

Received: 10.05.2019. Accepted: 20.06.2019. Published: 25.06.2019

This work is licensed under a Creative Commons Attribution 4.0 International License (http://creativecommons.org/ licenses/by/4.0). 